\title{
MODEL OPTIMISASI PORTOFOLIO INVESTASI MEAN- VARIANCE TANPA DAN DENGAN ASET BEBAS RISIKO PADA SAHAM IDX30
}

\author{
Basuki $^{1}$ ), Sukono ${ }^{2)}$, Ema Carnia ${ }^{\text {3) }}$ \\ 1) Program Studi Pendidikan Matematika STKIP Garut, \\ 1) Program Studi Magister Matematika FMIPA UNPAD \\ 2,3) Jurusan Matematika, Fakultas MIPA, Universitas Psdjadjaran \\ Jl. Raya Bandung Sumedang KM 21 Jatinangor Sumedang 45363 \\ Email: basuki0907@gmail.com, sukono@unpad.ac.id, sukono@unpad.ac.id
}

\begin{abstract}
ABSTRAK
Dalam paper ini, model optimisasi portofolio investasi Mean-Variance tanpa aset bebas risiko, atau disebut model dasar dari Markowitz telah dikaji untuk mendapatkan portofolio optimum. Berdasarkan model dasar dari Markowitz, kemudian dilakukan studi lebih lanjut pada model Mean-Variance dengan aset bebas risiko. Selanjutnya, kedua model tersebut digunakan untuk menganalisis optimisasi portofolio investasi pada beberapa saham IDX30. Dalam paper ini diasumsikan bahwa proporsi sebesar $10 \%$ diinvestasikan pada aset bebas risiko, berupa deposito yang memberikan return sebesar $7 \%$ per tahun. Berdasarkan hasil analisis optimisasi portofolio investasi pada lima saham yang dipilih didapatkan grafik permukaan efisien dari optimisasi portofolio Mean-Variance dengan aset bebas risiko, berada lebih tinggi dibandingkan optimisasi portofolio Mean-Variance tanpa aset bebas risiko. Dalam hal ini menunjukkan bahwa portofolio investasi kombinasi dari aset bebas risiko dan aset tanpa bebas risiko, lebih menguntungkan dibandingkan portofolio investasi yang hanya pada aset tanpa bebas risiko.
\end{abstract}

Kata Kunci:Return, risiko, portofolio investasi, model Markowitz, permukaan efisien.

\begin{abstract}
In this paper, the investment portfolio optimization model Mean-Variance without risk-free asset or socalled basic model of Markowitz has been examined to obtain optimum portfolio. Based on the basic model of Markowitz, then the further studies has been conducted into the model Mean-Variance with a risk-free asset. Furthermore, both models are used to analyze the investment portfolio optimization on some stocks IDX30. In this paper, it is assumed that the proportion of $10 \%$ is invested in risk-free assets, in the form of deposits that provide returns of $7 \%$ per year. Based on the analysis of investment portfolio optimization on five selected stocks obtained graph efficient frontier of Mean-variance optimization portfolio with a risk-free asset, are higher than the mean-variance portfolio optimization without the risk-free asset. In this case, it shows that the combination of the investment portfolio with and without risk-free asset, more profitable than the investment portfolio only on without risk-free asset.
\end{abstract}

Keyword: Return, risk, investment portfolio, Markowitz model, efficient frontier.

\section{Pendahuluan}

Investasi pada aset finansial cukup menarik minat bagi kebanyakan investor, baik investor lembaga maupun perorangan.Tandelilin (2010) menyatakan bahwa investasi adalah suatu komitmen untuk menanamkan sejumlah dana atau sumber daya lainnya yang dilakukan pada saat ini dengan tujuan memperoleh sejumlah keuntungan di masa datang. Jogiyanto (2016) menyatakan bahwa investasi adalah penundaan konsumsi sekarang untuk dimasukkan ke aktiva produktif selama periode waktu tertentu. Return harapan (expected return), bukanlah sebagai return pasti diterima tetapi merupakan hasil rata-rata dari seluruh hasil yang mungkin, dengan mengakui bahwa beberapa hasil berpeluang lebih besar untuk terjadi dibanding hasil yang lain dari berbagai skenario investasi (Bodie, et.al, 2014). Hubungan return harapan dan risiko suatu investasi merupakan hubungan yang searah dan linier. Pengukuran tingkat variabilitas return yang paling umum digunakan adalah variansi atau standar deviasi. Variansi digunakan untuk mengukur rata-rata selisih kuadrat antara return aktual dan ratarata return. Semakin besar nilai variansi, semakin jauh return aktual berbeda dari rata-rata return-nya.Untuk meminimumkan risiko investasi (Mangram, 2013; Solanki, 2014), investor 
perlu melakukan diversifikasi dengan membentuk portofolio investasi. Moehring, (2013) dalam penelitiannya menggunakan notasi matriks untuk menyederhanakan proses perhitungan optimisasi model Markowitz. Proses seleksi portofolio investasi model Markowitz, hakekatnya mengalokasikan sejumlah dana pada beberapa aset.

Dalam berinvestasi, investor bisa memilih menginvestasikan dananya baik hanya pada aset tanpa bebas risiko atau hanya pada aset bebas risiko, ataupun kombinasi dari kedua aset. Pilihan investor atas aset-aset tersebut, tergantung dari sejauh mana preferensi investor terhadap risiko. Semakin enggan seorang investor terhadap risiko (risk averse), maka pilihan investasinya akan cenderung lebih banyak pada aset bebas risiko. Aset bebas risiko adalah aset yang tingkat return-nya dimasa depan sudah bisa dipastikan pada saat ini, dan ditunjukkan oleh nilai variansi return sama dengan nol. Salah satu contoh aset bebas risiko adalah deposito atau obligasi jangka pendek yang diterbitkan pemerintah. Aset tanpa bebas risiko adalah aset yang tingkat return aktualnya di masa depan masih mengandung ketidakpastian. Salah satu contoh aset tanpa bebas risiko adalah saham. Persoalan mendasar dalam pembentukan portofolio efisien adalah menentukan pemilihan kombinasi aset supaya portofolio optimum.

Pembahasan paper ini bertujuan untuk menunjukkan analisis model optimisasi portofolio investasi Mean-Variance tanpa aset bebas risiko, selanjutnya dilakukan perluasan dengan memasukkan aset bebas risiko. Dari hasil analisis perhitungan return dan risiko portofolio, selanjutnya digunakan untuk menentukan komposisi bobot (proporsi) alokasi-dana pada masing-masing aset pembentuk portofolio optimum. Selanjutnya secara numerik dianalisis pula perbandingan antara optimisasi portofolio investasi Mean-Variance tanpa aset bebas risiko dan optimisasi portofolio investasi Mean-Variance dengan aset bebas risiko pada saham IDX30. Diharapkan penelitian ini bermanfaat untuk menambah literatur model optimisasi investasi, khususnya konsentrasi Matematika Keuangan, dan dijadikan sebagai tambahan referensi penelitian lanjutan, serta dijadikan sebagai salah satu alternatif bagi investor dalam melakukan optimisasi portofolio investasi.

\section{Metode Penelitian}

Untuk pemilihan portofolio efisien, misal diberikan portofolio $p$ dengan vektor bobot $\mathbf{w}$, merujuk Panjer et al.(1998) dan Ruppert (2004) serta Ryck et al.(2007), dilakukan dengan cara mencari nilai maksimum $2 \tau \mu_{p}-\sigma_{p}^{2}$, syarat $\sum_{i=1}^{N} w_{i}=1$ dan $\tau \geq 0$, parameter $\tau$ disebut toleransi risiko. Menggunakan pendekatan model Markowitz, persoalan optimisasi yang akan diselesaikan memiliki beberapa keuntungan yaitu: (i) Toleransi risiko $\tau$ yang harus ditentukan dan (ii) Momen pertama $\mu_{i}$ dan momen kedua $\sigma_{i j}$ yang diperlukan dari return aset.

\subsection{Optimisasi Portofolio Investasi Mean-Variance Tanpa Aset Bebas Risiko}

Misalkan terdapat $N$ aset tanpa bebas risiko dengan return $r_{1}, \ldots r_{N}$. Diasumsikan bahwa momen pertama dan kedua dari $r_{1}, \ldots r_{N}$ ada, vektor transpose nilai ekspektasi return dinyatakan sebagai: $\boldsymbol{\mu}^{T}=\left(\mu_{1}, \ldots, \mu_{N}\right)$ dengan $\mu_{i}=E\left[r_{i}\right], i=1, \ldots, N$ dan matriks kovariansi dinyatakan sebagai: $\boldsymbol{\Sigma}=\left(\sigma_{i j}\right)$ dengan $\sigma_{i j}=\operatorname{Cov}\left(r_{i}, r_{j}\right), i, j=1, \ldots, N$. Jika return portofolio $r_{p}$ dengan vektor bobot transpose $\mathbf{w}^{T}=\left(w_{1}, \ldots, w_{N}\right)$, dan syarat $\sum_{i=1}^{N} w_{i}=1$, maka ekspektasi return portofolio dengan menggunakan notasi vektor, dapat dinyatakan sebagai:

$$
\mu_{p}=E\left[r_{p}\right]=\boldsymbol{\mu}^{T} \mathbf{w}=\mathbf{w}^{T} \boldsymbol{\mu}
$$

dan variansi portopolio dapat dinyatakan sebagai:

$$
\sigma_{p}^{2}=\operatorname{Var}\left(r_{p}\right)=\mathbf{w}^{T} \boldsymbol{\Sigma} \mathbf{w}
$$


Dalam optimisasi Mean-Variance, portofolio efisien didefinisikan sebagai berikut.

Definisi : Suatu portofolio $p^{*}$ disebut (Mean-Variance) efisien jika tidak ada portofolio $p$ dengan $\mu_{p} \geq \mu_{p^{*}}$ dan $\sigma_{p}^{2}<\sigma_{p^{*}}^{2}$ (Panjer et al., 1998; Rupert, 2004).

Untuk mendapatkan portofolio efisien, berarti harus menyelesaikan persoalan optimisasi portofolio sebagai berikut:

$$
\begin{gathered}
\text { Maksimumkan }\left\{2 \tau \boldsymbol{\mu}^{T} \mathbf{w}-\mathbf{w}^{T} \boldsymbol{\Sigma} \mathbf{w}\right\}, \\
\text { syarat } \mathbf{e}^{T} \mathbf{w}=1
\end{gathered}
$$

dengan $\mathbf{e}^{T}=(1, \ldots, N), \boldsymbol{\mu}^{T} \mathbf{w}=\mathbf{w}^{T} \boldsymbol{\mu}$, dan $\mathbf{w}^{T} \mathbf{e}=\mathbf{e}^{T} \mathbf{w}$. Fungsi Lagrange persamaan (3) dimana $\lambda$ sebagai pengalinya, dapat dinyatakan sebagai berikut:

$$
L(\mathbf{w}, \lambda)=\left(2 \tau \mathbf{w}^{T} \boldsymbol{\mu}-\mathbf{w}^{T} \mathbf{\Sigma} \mathbf{w}\right)+\lambda\left(\mathbf{w}^{T} \mathbf{e}-1\right)
$$

Persamaan (4) dengan menggunakan syarat perlu teorema Kuhn-Tucker $\frac{\partial L}{\partial \mathbf{w}}=0$ dan $\frac{\partial L}{\partial \lambda}=0$, didapat:

$$
\begin{aligned}
& \frac{\partial L}{\partial \mathbf{w}}=2 \tau \boldsymbol{\mu}-2 \boldsymbol{\Sigma} \mathbf{w}+\lambda \mathbf{e}=0 \\
& \frac{\partial L}{\partial \lambda}=\mathbf{w}^{T} \mathbf{e}-1=0
\end{aligned}
$$

Persamaan (5) kalikan $\boldsymbol{\Sigma}^{-1}$ dan nyatakan dalam $\mathbf{w}$, kemudian hasilnya kalikan $\mathbf{e}^{T}$, setelah dilakukan penyelesaian didapat:

$$
\mathbf{w}=\frac{1}{\mathbf{e}^{T} \boldsymbol{\Sigma}^{-1} \mathbf{e}} \boldsymbol{\Sigma}^{-1} \mathbf{e}+\tau\left\{\boldsymbol{\Sigma}^{-\mathbf{1}} \boldsymbol{\mu}-\frac{\mathbf{e}^{T} \boldsymbol{\Sigma}^{-1} \boldsymbol{\mu}}{\mathbf{e}^{T} \boldsymbol{\Sigma}^{-1} \mathbf{e}} \boldsymbol{\Sigma}^{-\mathbf{1}} \mathbf{e}\right\} ; \tau \geq 0
$$

Pada saat $\tau=0$ menghasilkan portofolio variansi minimum dengan bobot:

$$
\mathbf{w}^{\operatorname{Min}}=\frac{1}{\mathbf{e}^{T} \boldsymbol{\Sigma}^{-1} \mathbf{e}} \boldsymbol{\Sigma}^{-1} \mathbf{e}
$$

Selanjutnya, peneliti melakukan perluasan model optimisasi portofolio investasi MeanVariance dengan memasukan aset bebas risiko.

\subsection{Optimisasi Portofolio Investasi Mean-Variance Dengan Aset Bebas Risiko}

Misalkan investor dalam pembentukan portofolio investasi, menyisihkan sebagian proporsi modalnya sebesar $w_{0}$ untuk diinvestasikan pada aset bebas risiko, dimana aset bebas risiko tersebut memberikan return tetap sebesar $r_{0}$ per satuan waktu. Sebagian lagi proporsi sebesar $w_{i}(i=1, \ldots, N)$ diinvestasikan pada aset tanpa bebas risiko, masing-masing aset return-nya sebesar $r_{i}(i=1, \ldots, N)$. Sehingga, total return dari portofolio investasi dapat dinyatakan sebagai:

$$
r_{p}=w_{0} r_{0}+\sum_{i=1}^{N} w_{i} r_{i}
$$


Misalkan $\mathbf{w}=\left(w_{1}, \ldots, w_{N}\right)^{T}$ vektor bobot portofolio investasi, $\mathbf{r}=\left(r_{1}, \ldots, r_{N}\right)^{T}$ vektor return dan $\boldsymbol{\mu}=\left(\mu_{1}, \ldots, \mu_{N}\right)^{T}$ vektor rataan (mean) dari return masing-masing aset tanpa bebas risiko, dengan demikian persamaan (8) dapat dinyatakan sebagai:

$$
r_{p}=w_{0} r_{0}+\mathbf{w}^{T} \mathbf{r} \text {. }
$$

Oleh karena itu, ekspektasi dari return portofolio $\mu_{p}$ dapat dinyatakan sebagai:

$$
\mu_{p}=E\left(r_{p}\right)=E\left(w_{0} r_{0}+\mathbf{w}^{T} \mathbf{r}\right)=w_{0} \mu_{0}+\mathbf{w}^{T} \boldsymbol{\mu} .
$$

Jika diberikan $\boldsymbol{\Sigma}$ adalah matriks kovariansi, maka variansi (risiko) return portofolio dapat dinyatakan sebagai:

$$
\sigma_{p}^{2}=\operatorname{Var}\left(r_{p}\right)=\mathbf{w}^{T} \mathbf{\Sigma} \mathbf{w}
$$

Sehingga model optimisasi portofolio investasi Mean-Variance dengan aset bebas risiko dapat dinyatakan sebagai:

$$
\begin{gathered}
\text { Maksimumkan }\left\{w_{0} \mu_{0}+2 \mathbf{w}^{T} \boldsymbol{\mu}-\mathbf{w}^{T} \boldsymbol{\Sigma} \mathbf{w}\right\}, \\
\text { syarat }\left(w_{0}+\mathbf{w}^{T} \mathbf{e}\right)=1
\end{gathered}
$$

dimana $\mathbf{e}=(1, \ldots, 1)$ vektor satuan. Untuk melakukan proses optimisasi dilakukan dengan teknik Lagrange multiplier dan harus memenuhi syarat perlu teorema Kuhn-Tucker. Fungsi Lagrange persamaan (12) dengan $\lambda$ sebagai pengalinya dapat dinyatakan sebagai berikut:

$$
L(\mathbf{w}, \lambda)=\left\{w_{0} \mu_{0}+2 \tau \mathbf{w}^{T} \boldsymbol{\mu}-\mathbf{w}^{T} \mathbf{\Sigma} \mathbf{w}\right\}+\lambda\left(w_{0}+\mathbf{w}^{T} \mathbf{e}-1\right)
$$

Syarat perlu teorema Kuhn-Tucker pada persamaan (13) adalah $\frac{\partial L}{\partial \mathbf{w}}=0$ dan $\frac{\partial L}{\partial \lambda}=0$, didapat:

$$
\begin{aligned}
& \frac{\partial L}{\partial \mathbf{w}}=2 \tau \boldsymbol{\mu}-2 \boldsymbol{\Sigma} \mathbf{w}+\lambda \mathbf{e}=0 \\
& \frac{\partial L}{\partial \lambda}=w_{0}+\mathbf{w}^{T} \mathbf{e}-1=0 .
\end{aligned}
$$

Persamaan (14) kalikan dengan $\mathbf{\Sigma}^{-1}$ dan nyatakan dalam $\mathbf{w}$, sehingga didapat persamaan:

$$
\mathbf{w}=\tau \boldsymbol{\Sigma}^{-1} \boldsymbol{\mu}+\frac{\lambda}{2} \boldsymbol{\Sigma}^{-1} \mathbf{e}
$$

Persamaan (16) kalikan dengan $\mathbf{e}^{T}$, didapat persamaan:

$$
\mathbf{e}^{T} \mathbf{w}=\tau \mathbf{e}^{T} \boldsymbol{\Sigma}^{-1} \boldsymbol{\mu}+\frac{\lambda}{2} \mathbf{e}^{T} \boldsymbol{\Sigma}^{-1} \mathbf{e}
$$

Persamaan (17) dengan $\mathbf{w}^{T} \mathbf{e}=\mathbf{e}^{T} \mathbf{w}$, jika disubstitusikan pada persamaan (15) didapat:

$$
1-w_{0}=\tau \mathbf{e}^{T} \boldsymbol{\Sigma}^{-1} \boldsymbol{\mu}+\frac{\lambda}{2} \mathbf{e}^{T} \boldsymbol{\Sigma}^{-1} \mathbf{e}
$$

Sehingga besarnya nilai $\frac{\lambda}{2}=\frac{1-w_{0}-\tau \mathbf{e}^{T} \boldsymbol{\Sigma}^{-1} \boldsymbol{\mu}}{\mathbf{e}^{T} \boldsymbol{\Sigma}^{-1} \mathbf{e}}$, dan jika nilai $\frac{\lambda}{2}$ tersebut disubstitusikan pada persamaan (16), maka diperoleh vektor bobot $\mathbf{w}$ dengan persamaan sebagai berikut:

$$
\mathbf{w}=\tau \boldsymbol{\Sigma}^{-1} \boldsymbol{\mu}+\frac{1-w_{0}-\tau \mathbf{e}^{T} \boldsymbol{\Sigma}^{-1} \boldsymbol{\mu}}{\mathbf{e}^{T} \boldsymbol{\Sigma}^{-1} \mathbf{e}} \boldsymbol{\Sigma}^{-1} \mathbf{e}, \tau \geq 0
$$

Faktor toleransi risiko dalam proses optimisasi ini, menggunakan bantuan software Matlab 2013, ditentukan secara simulasi dari nilai awal 0 (nol), kemudian ditingkatkan secara bertahap dengan delta peningkatan tertentu. Proses peningkatan faktor toleransi risiko dihentikan ketika diperoleh vektor bobot bernilai negatif. Hal ini merujuk asusmi bahwa short sales tidak diperkenankan dalam jual beli saham. Dari proses optimisasi ini, setiap vektor bobot yang diperoleh, digunakan untuk menghitung ekspektasi return portofolio pada persamaan (1) untuk aset tanpa bebas risiko dan persamaan (10) untuk aset dengan bebas risiko. Sedangkan untuk menghitung variansi (risiko), menggunakan persamaan (2) untuk aset tanpa bebas risiko 
dan persamaan (11) untuk aset dengan bebas risiko. Setiap pasangan antara ekspektasi return dan variansi portofolio, membentuk sebuah titik portofolio efisien suatu nilai toleransi risiko. Himpunan titik-titik portofolio efisien tersebut digunakan untuk membentuk grafik (kurva) permukaan efisien (eficient frontier) dari masing-masing model portofolio investasi MeanVariance. Menggunakan estimator ekspektasi return dan variansi (risiko) portofolio, dapat ditentukan rasio antara ekspektasi return terhadap risiko portofolio. Nilai rasio ini selanjutnya digunakan untuk memilih portofolio optimum global, yaitu portofolio yang memiliki rasio terbesar. Selanjutnya, peneliti melakukan pembahasan menggunakan data secara numerik untuk model portofolio investasi Mean-Variance tanpa dan dengan aset bebas risiko pada saham IDX30, dan dilanjutkan melakukan analisis perbandingan menggunakan beberapa karakteristik penting dari dua model optimisasi investasi tersebut.

\section{Hasil dan Pembahasan}

\subsection{Statistik Data}

Data saham dalam obyek penelitian ini adalah data saham yang diperdagangkan pada pasar modal melalui Bursa Efek Indonesia (BEI) yang masuk dalam daftar indeks IDX30. Data historis harian diakses melalui website http://finance.yahoo.com terdiri 30 (tigapuluh) saham periode 1 Agustus 2014 - 31 Juli 2016. Dari 30 saham tersebut, dipilih saham-saham yang selalu terdaftar pada 4 (empat) periode penelitian, dan ternyata hanya 20 saham yang masuk nominasi yaitu saham: ADHI, ADRO, ASII, BBCA, BBNI, BBRI, BMRI, GGRM, ICBP, INDF, INTP, KLBF, LPKR, LPPF, MNCN, PGAS, SMGR, TLKM, UNTR, UNVR. Selanjutnya dengan menggunakan bantuan software Eviews 9, dilakukan estimasi distribusi, ekspektasi (mean) dan variansi return saham, serta rasio antara ekspektasi dan variansi return saham. Dimisalkan investor akan membentuk portofolio investasi, terdiri dari 5 (lima) saham terbaik yang dipilih berdasarkan nilai rasio terbesar. Lima saham terpilih, dirangkum dalam Tabel 1.

Tabel 1.Lima saham terpilih

\begin{tabular}{|c|c|c|c|c|c|}
\hline $\begin{array}{c}\text { Nama } \\
\text { Saham }\end{array}$ & $\begin{array}{c}\text { Estimator } \\
\text { distribusi }\end{array}$ & $\begin{array}{c}\text { Anderson } \\
\text { Darling }\end{array}$ & $\begin{array}{c}\text { Ekspektasi/ } \\
\text { rataan } \boldsymbol{\mu}\end{array}$ & $\begin{array}{c}\text { Variansi } \\
\boldsymbol{\sigma}^{2}\end{array}$ & Rasio $\frac{\boldsymbol{\mu}}{\boldsymbol{\sigma}^{2}}$ \\
\hline TLKM & Normal & 5.08593 & 0.00092 & 0.00022 & 4.111431 \\
\hline UNVR & Normal & 4.50472 & 0.00075 & 0.00033 & 2.27411 \\
\hline BBCA & Normal & 12.24996 & 0.00041 & 0.00019 & 2.161392 \\
\hline LPPF & Normal & 3.28078 & 0.00062 & 0.00064 & 0.981272 \\
\hline GGRM & Normal & 4.35404 & 0.00043 & 0.00045 & 0.961145 \\
\hline
\end{tabular}

Dari 5 (lima) saham terpilih pada Tabel 1, selanjutnya dengan menggunakan bantuan software excel ditentukan estimasi nilai kovariansi antar saham, seperti dirangkum dalam Tabel 2.

Tabel 2.Estimator kovariansi 5 saham terpilih

\begin{tabular}{|c|c|c|c|c|c|c|}
\hline & & TLKM & UNVR & BBCA & LPPF & GGRM \\
\hline 1 & TLKM & 0.00022 & 0.00010 & -0.00001 & 0.00011 & 0.00005 \\
\hline 2 & UNVR & 0.00010 & 0.00033 & 0.00000 & 0.00014 & 0.00010 \\
\hline 3 & BBCA & -0.00001 & 0.00000 & 0.00019 & -0.00001 & -0.00001 \\
\hline 4 & LPPF & 0.00011 & 0.00014 & -0.00001 & 0.00064 & 0.00011 \\
\hline 5 & GGRM & 0.00005 & 0.00010 & -0.00001 & 0.00011 & 0.00045 \\
\hline
\end{tabular}

Dari 5 (lima) saham terpilih pada Tabel 1., estimator nilai rataan $\boldsymbol{\mu}_{i},(i=1, \ldots, 5)$ dibentuk vektor transpose rataan $\boldsymbol{\mu}^{T}=\left(\begin{array}{lllll}0.00092 & 0.00075 & 0.00041 & 0.00062 & 0.00043\end{array}\right)$, kemudian dibentuk vektor transpose satuan $\mathbf{e}^{T}=\left(\begin{array}{lllll}1 & 1 & 1 & 1 & 1\end{array}\right)$. Selanjutnya dari Tabel 2 estimator nilai variansi $\sigma_{i}^{2},(i=1, \ldots, 5)$ bersama estimator kovariansi antar return saham, digunakan untuk membentuk matriks kovariansi $\boldsymbol{\Sigma}$. Menggunakan bantuan software excell, dapat ditentukan 
invers matriks kovariansi $\boldsymbol{\Sigma}^{-1}$. Matriks kovariansi $\boldsymbol{\Sigma}$ dan invers matriks kovariansi $\boldsymbol{\Sigma}^{-1}$ dinyatakan sebagai berikut:

$$
\Sigma=\left[\begin{array}{ccccc}
0.00022 & 0.00010 & -0.00001 & 0.00011 & 0.00005 \\
0.00010 & 0.00033 & 0.00000 & 0.00014 & 0.00010 \\
-0.00001 & 0.00000 & 0.00019 & -0.00001 & -0.00001 \\
0.00011 & 0.00014 & -0.00001 & 0.00064 & 0.00011 \\
0.00005 & 0.00010 & -0.00001 & 0.00011 & 0.00045
\end{array}\right], \Sigma^{-1}=\left[\begin{array}{ccccc}
5,377.99 & -1,279.15 & 244.21 & -619.52 & -135.90 \\
-1,279.15 & 3,801.33 & -37.78 & -509.03 & -583.76 \\
244.21 & -37.78 & 5,340.60 & 8.95 & 125.97 \\
-619.52 & -509.03 & 8.95 & 1,841.47 & -286.09 \\
-135.90 & -583.76 & 125.97 & -286.09 & 2,447.34
\end{array}\right]
$$

Selanjutnya, invers matriks kovariansi $\mathbf{\Sigma}^{-1}$ digunakan untuk proses perhitungan komposisi bobot portofolio efisien pada dua model dengan menggunakan bantuan software Matlab 2013.

\subsection{Proses Optimisasi Portofolio Investasi Mean-Variance Tanpa Aset Bebas Risiko}

Persoalan optimisasi portofolio Mean-Variance tanpa aset bebas risiko disusun merujuk pada persamaan (3). Menggunakan vektor $\boldsymbol{\mu}^{T}$ dan $\mathbf{e}^{T}$ serta matriks $\boldsymbol{\Sigma}^{-1}$, selanjutnya vektor bobot $\mathbf{w}$ dihitung menggunakan persamaan (7). Toleransi risiko $\tau$ dengan syarat $\tau \geq 0$ dalam optimisasi portofolio investasi, disimulasikan dengan mengambil beberapa nilai yang memenuhi syarat $\mathbf{e}^{T} \mathbf{w}=1$. Pengambilan nilai toleransi risiko dihentikan, apabila untuk suatu nilai toleransi risiko setelah disubstitusikan ke dalam persamaan (7) menghasilkan suatu bobot $w_{i}(i=1, \ldots, 5)$ yang bukan merupakan bilangan riil positif dan memenuhi $\mathbf{e}^{T} \mathbf{w}=1$. Untuk mempermudah perhitungan, digunakan bantuan software Matlab 2013. Adapun pengambilan nilai-nilai toleransi risiko dan hasil penghitungan komposisi bobot portofolio efisien diberikan dalam Tabel 3.

Tabel 3.Proses optimisasi portofolio investasi Mean-Variance tanpa aset bebas risiko pada saham IDX30

\begin{tabular}{|c|c|c|c|c|c|c|c|c|c|}
\hline$\tau$ & TLKM & BBCA & UNVR & LPPF & GGRM & $\mathbf{w}^{T} \mathbf{e}$ & $\mu_{p}$ & $\sigma_{p}^{2}$ & $\mu_{p} / \sigma_{p}^{2}$ \\
\hline 0 & 0.327365 & 0.381009 & 0.137309 & 0.018261 & 0.136057 & 1 & 0.000637 & 0.000129 & 4.922141 \\
\hline 0.01 & 0.347036 & 0.359995 & 0.1419 & 0.018327 & 0.132741 & 1 & 0.000648 & 0.00013 & 5.003133 \\
\hline 0.02 & 0.366708 & 0.338981 & 0.146491 & 0.018394 & 0.129426 & 1 & 0.000659 & 0.00013 & 5.075349 \\
\hline 0.03 & 0.38638 & 0.317968 & 0.151082 & 0.01846 & 0.126111 & 1 & 0.00067 & 0.00013 & 5.138486 \\
\hline 0.04 & 0.406052 & 0.296954 & 0.155673 & 0.018526 & 0.122795 & 1 & 0.000681 & 0.000131 & 5.192343 \\
\hline 0.05 & 0.425724 & 0.27594 & 0.160264 & 0.018593 & 0.11948 & 1 & 0.000692 & 0.000132 & 5.236811 \\
\hline 0.06 & 0.445395 & 0.254926 & 0.164855 & 0.018659 & 0.116165 & 1 & 0.000703 & 0.000133 & 5.27188 \\
\hline 0.07 & 0.465067 & 0.233912 & 0.169446 & 0.018725 & 0.112849 & 1 & 0.000714 & 0.000135 & 5.297631 \\
\hline 0.08 & 0.484739 & 0.212898 & 0.174037 & 0.018792 & 0.109534 & 1 & 0.000725 & 0.000137 & 5.314233 \\
\hline 0.09 & 0.504411 & 0.191885 & 0.178628 & 0.018858 & 0.106219 & 1 & 0.000736 & 0.000138 & 5.321936 \\
\hline 0.1 & 0.524082 & 0.170871 & 0.183219 & 0.018924 & 0.102904 & 1 & 0.000747 & 0.00014 & 5.321058 \\
\hline 0.11 & 0.543754 & 0.149857 & 0.18781 & 0.018991 & 0.099588 & 1 & 0.000759 & 0.000143 & 5.311983 \\
\hline 0.12 & 0.563426 & 0.128843 & 0.192401 & 0.019057 & 0.096273 & 1 & 0.00 & 0.000 & 5.295144 \\
\hline 0.13 & 0.583098 & 0.107829 & 0.196992 & 0.019123 & 0.092958 & 1 & 0.000781 & 0.000148 & 5.271015 \\
\hline 0.14 & 0.602769 & 0.086815 & 0.201583 & 0.01919 & 0.089642 & 1 & 0.000792 & 0.000151 & 5.240102 \\
\hline 0.15 & 0.622441 & 0.065801 & 0.206174 & 0.019256 & 0.086327 & 1 & 0.000803 & 0.000154 & 5.20293 \\
\hline 0.16 & 0.642113 & 0.044788 & 0.210765 & 0.019323 & 0.083012 & 1 & 0.000814 & 0.000158 & 5.160037 \\
\hline 0.17 & 0.661785 & 0.023774 & 0.215356 & 0.019389 & 0.079696 & 1 & 0.000825 & 0.000161 & 5.111962 \\
\hline 0.18 & 0.681456 & 0.00276 & 0.219947 & 0.019455 & 0.076381 & 1 & 0.000836 & 0.000165 & 5.059241 \\
\hline 0.19 & 0.701128 & -0.01825 & 0.224538 & 0.019522 & 0.073066 & 1 & 0.000847 & 0.000169 & 5.002398 \\
\hline
\end{tabular}


Serangkaian portofolio efisien berada pada permukaan efisien (efficient frontier).Efficient frontier adalah permukaan efisien di mana terletak portofolio-portofolio yang return-nya sepadan dengan risikonya. Menggunakan bantuan software Matlab 2013, kurva Efficient frontier dan rasio antara return rata-rata terhadap variansi portofolio tampak seperti pada Gambar 1.
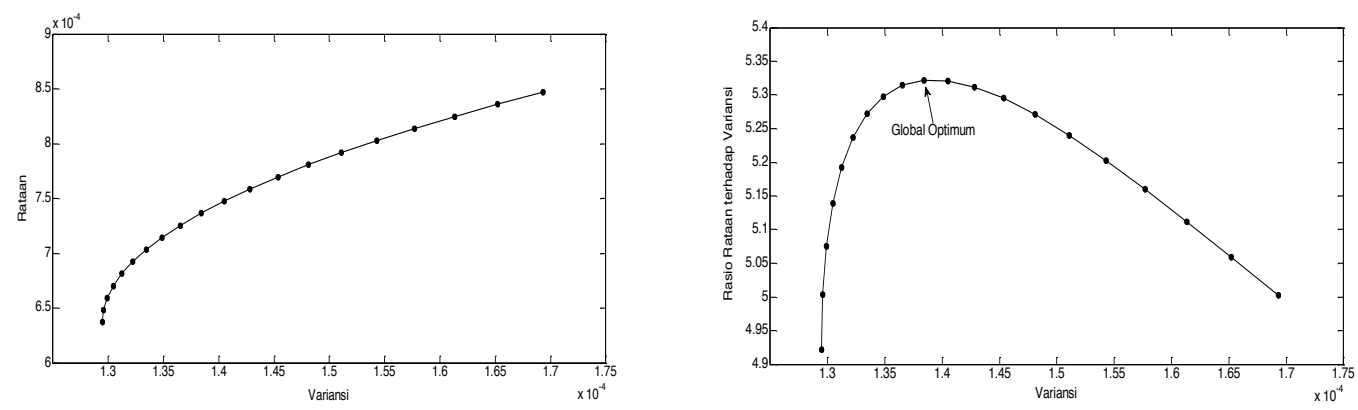

Gambar 1.Efficient frontier dan rasio portofolio Mean-Variance tanpa aset bebas risiko pada saham IDX30

\subsection{Proses Optimisasi Portofolio Investasi Mean-Variance Dengan Aset Bebas Risiko}

Untuk melakukan proses optimisasi portofolio investasi dengan aset bebas risiko pada saham IDX30. Misalkan investor mengalokasikan proporsi sebesar $w_{0}=10 \%$ diinvestasikan pada asset bebas risiko, yang memberikan return rataan sebesar $7 \%$ per tahun atau setara dengan $\mu_{0}=0.000192$ per hari.Persoalan optimisasi portofolio Mean-Variance dengan aset bebas risiko disusun merujuk pada persamaan (12). Menggunakan vektor $\boldsymbol{\mu}^{T}$ dan $\mathbf{e}^{T}$ serta matriks $\Sigma^{-1}$, vektor bobot $\mathbf{w}$ dihitung menggunakan persamaan (18). Toleransi risiko $\tau$ dengan syarat $\tau \geq 0$ dalam proses optimisasi portofolio di sini disimulasikan dengan mengambil beberapa nilai yang memenuhi syarat $w_{0}+\mathbf{w}^{T} \mathbf{e}=1$. Pengambilan nilai toleransi risiko dihentikan apabila untuk suatu nilai toleransi risiko setelah disubstitusikan pada persamaan (18) menghasilkan suatu bobot $w_{i}(i=1, \ldots, 5)$ yang bukan merupakan bilangan riil positif dan memenuhi $w_{0}+\mathbf{w}^{T} \mathbf{e}=1$. Untuk mempermudah perhitungan, digunakan bantuan software Matlab 2013. Adapun pengambilan nilai-nilai toleransi risiko dan hasil penghitungan komposisi bobot portofolio efisien diberikan dalam Tabel 4.

Kurva Efficient frontier dan rasio antara return rata-rata terhadap variansi portofolio investasi dengan aset bebas risiko tampak seperti pada Gambar 2.
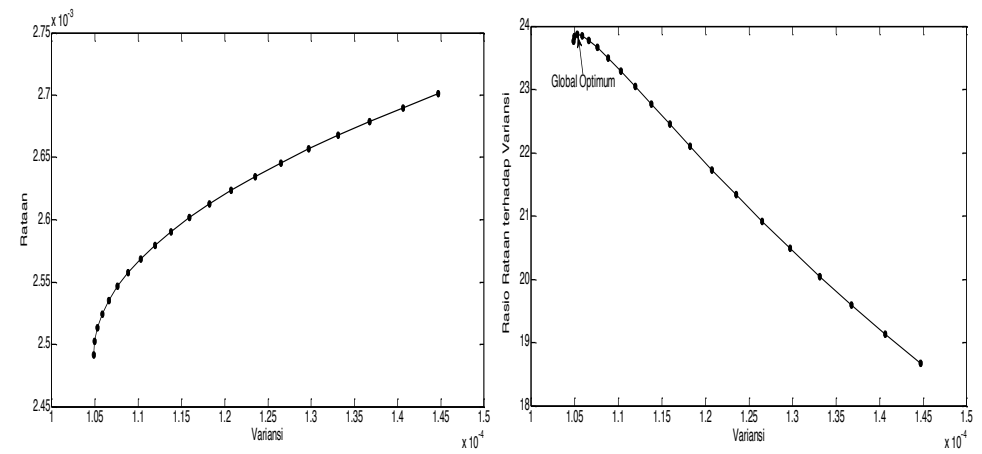

Gambar 2. Efficient frontier dan rasio portofolio Mean-Variance dengan aset bebas risiko pada saham IDX30 
Tabel 4.Proses optimisasi portofolio Mean-Variance dengan aset bebas risiko pada saham IDX30

\begin{tabular}{|c|c|c|c|c|c|c|c|c|c|c|}
\hline$\tau$ & TLKM & BBCA & UNVR & LPPF & GGRM & $w_{0}+\mathbf{w}^{T} \mathbf{e}$ & $\mu_{0}$ & $\mu_{p}$ & $\sigma_{p}^{2}$ & $\mu_{p} / \sigma_{p}^{2}$ \\
\hline 0 & 0.294628 & 0.342908 & 0.123578 & 0.016435 & 0.122451 & 1 & 0.019178 & 0.002491 & 0.000105 & 23.76018 \\
\hline 0.01 & 0.3143 & 0.321894 & 0.128169 & 0.016501 & 0.119136 & 1 & 0.019178 & 0.002502 & 0.000105 & 23.84034 \\
\hline 0.02 & 0.333972 & 0.300881 & 0.13276 & 0.016568 & 0.11582 & 1 & 0.019178 & 0.002513 & 0.000105 & 23.87019 \\
\hline 0.03 & 0.353644 & 0.279867 & 0.137351 & 0.016634 & 0.112505 & 1 & 0.019178 & 0.002524 & 0.000106 & 23.85002 \\
\hline 0.04 & 0.373315 & 0.258853 & 0.141942 & 0.0167 & 0.10919 & 1 & 0.019178 & 0.002535 & 0.000107 & 23.78071 \\
\hline 0.05 & 0.392987 & 0.237839 & 0.146533 & 0.016767 & 0.105874 & 1 & 0.019178 & 0.002546 & 0.000108 & 23.66377 \\
\hline 0.06 & 0.412659 & 0.216825 & 0.151124 & 0.016833 & 0.102559 & 1 & 0.019178 & 0.002557 & 0.000109 & 23.5012 \\
\hline 0.07 & 0.432331 & 0.195811 & 0.155715 & 0.016899 & 0.099244 & 1 & 0.019178 & 0.002568 & 0.00011 & 23.29549 \\
\hline 0.08 & 0.452002 & 0.174797 & 0.160306 & 0.016966 & 0.095928 & 1 & 0.019178 & 0.00258 & 0.000112 & 23.04952 \\
\hline 0.09 & 0.471674 & 0.153784 & 0.164897 & 0.017032 & 0.092613 & 1 & 0.019178 & 0.002591 & 0.000114 & 22.76647 \\
\hline 0.1 & 0.491346 & 0.13277 & 0.169488 & 0.017098 & 0.089298 & 1 & 0.019178 & 0.002602 & 0.000116 & 22.44976 \\
\hline 0.11 & 0.511018 & 0.111756 & 0.174079 & 0.017165 & 0.085983 & 1 & 0.019178 & 0.002613 & 0.000118 & 22.10296 \\
\hline 0.12 & 0.530689 & 0.090742 & 0.17867 & 0.017231 & 0.082667 & 1 & 0.019178 & 0.002624 & 0.000121 & 21.7297 \\
\hline 0.13 & 0.550361 & 0.069728 & 0.183261 & 0.017297 & 0.079352 & 1 & 0.019178 & 0.002635 & 0.000124 & 21.33361 \\
\hline 0.14 & 0.570033 & 0.048714 & 0.187852 & 0.017364 & 0.076037 & 1 & 0.019178 & 0.002646 & 0.000126 & 20.91827 \\
\hline 0.15 & 0.589705 & 0.027701 & 0.192443 & 0.01743 & 0.072721 & 1 & 0.019178 & 0.002657 & 0.00013 & 20.48711 \\
\hline 0.16 & 0.609376 & 0.006687 & 0.197034 & 0.017496 & 0.069406 & 1 & 0.019178 & 0.002668 & 0.000133 & 20.04344 \\
\hline 0.17 & 0.629048 & -0.01433 & 0.201625 & 0.017563 & 0.066091 & 1 & 0.019178 & 0.002679 & 0.000137 & 19.59032 \\
\hline
\end{tabular}




\subsection{Analisis Perbandingan}

Analisis perbandingan dari hasil proses optimisasi dua model tersebut, dilakukan dengan cara memperhatikan beberapa karakteristik penting secara numerik pada Tabel 3 dan Tabel 4 dijelaskan sebagai berikut:

a. Toleransi risiko untuk model Mean-Variance tanpa aset bebas risiko pada saham IDX30 berkisar $0 \leq \tau \leq 0.18$; sedangkan untuk model Mean-Variance dengan aset bebas risiko pada saham IDX30 berkisar $0 \leq \tau \leq 0.16$

b. Portofolio minimum untuk model Mean-Variance tanpa aset bebas risiko pada saham IDX30 didapat rataan return sebesar 0.000637 dengan variansi sebesar 0.000129; sedangkan untuk model Mean-Variance dengan aset bebas risiko pada saham IDX30 didapat rataan return sebesar 0.002491 dengan variansi sebesar 0.000105 .

c. Portofolio maksimum untuk model Mean-Variance tanpa aset bebas risiko pada saham IDX30 didapat rataan return sebesar 0.000836 dengan variansi sebesar 0.000165 ; sedangkan untuk model Mean-Variance dengan aset bebas risiko pada saham IDX30 didapat rataan return sebesar 0.002668 dengan variansi sebesar 0.000133 .

d. Portofolio optimum untuk model Mean-Variance tanpa aset bebas risiko pada saham IDX30 didapat rataan return sebesar 0.000736 dengan variansi sebesar 0.000138; sedangkan untuk model Mean-Variance dengan aset bebas risiko pada saham IDX30 didapat rataan return sebesar 0.002513 dengan variansi sebesar 0.000105 .

e. Bobot portofolio optimum untuk model Mean-Variance tanpa aset bebas risiko pada saham IDX30 proporsi saham TLKM=0.504411; BBCA=0.191885; UNVR=0.178628; $\mathrm{LPPF}=0.018858$ dan GGRM=0.106219. Sedangkan bobot portofolio optimum untuk model Mean-Variance dengan aset bebas risiko pada saham IDX30 proporsi saham $\mathrm{TLKM}=0.333972 ; \mathrm{BBCA}=0.300881 ; \mathrm{UNVR}=0.132760 ; \mathrm{LPPF}=0.016568$ dan GGRM=0.115820.

Menggunakan bantuan software Matlab 2013, perbandingan kurva permukaan efisien dari portofolio Mean-Variance tanpa dan dengan aset bebas risiko pada saham IDX30, seperti tampak pada Gambar3.

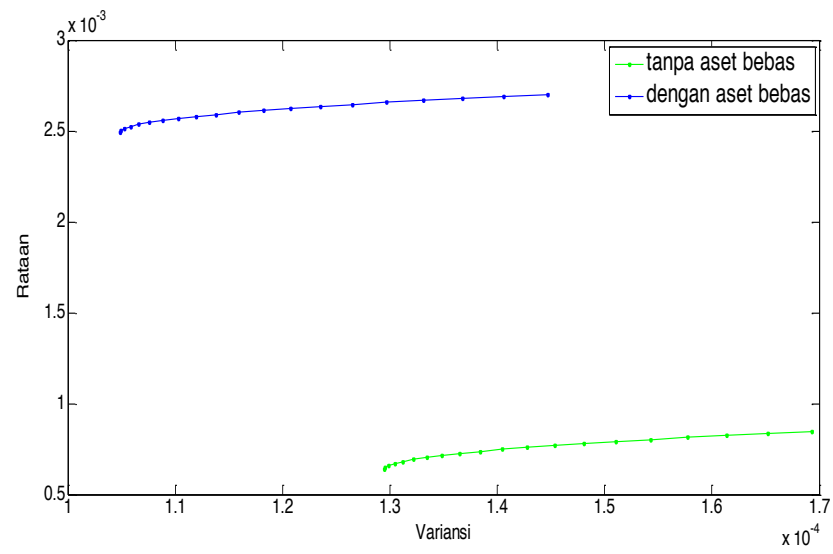

Gambar 3. Grafik Perbandingan Efficient frontier

Jika memperhatikan grafik pada Gambar 3, maka tampak bahwa kurva permukaan efisien untuk portofolio model Mean-Variance dengan aset bebas risiko, lebih tinggi dibandingkan portofolio model Mean-Variance tanpa aset bebas risiko. Dalam hal ini menggambarkan bahwa return investasi yang menggabungkan tanpa dan dengan aset bebas risiko pada saham IDX30, lebih menguntungkan dibandingkan return investasi hanya pada aset tanpa bebas risiko. Selain itu, variansi pada investasi yang menggabungkan tanpa dan dengan aset bebas risiko pada saham IDX30, lebih kecil dibandingkan dengan investasi hanya pada aset tanpa bebas risiko. 


\section{Simpulan}

Untuk menentukan alokasi bobot portofolio investasi yang optimum pada asset tanpa bebas risiko, dapat digunakan model optimisasi portofolio investasi Mean-Variance yang merupakan model dasar dari Markowitz. Perluasan model optimisasi portofolio investasi MeanVariance dilakukan dengan cara memasukan aset bebas risiko pada saham IDX30. Dari perluasan ini, dapat diturunkan formula untuk menentukan alokasi bobot portofolio optimum. Jika diasumsikan investor menyisihkan sebesar $10 \%$ dananya untuk diinvestasikan pada aset bebas risiko (deposito), dan aset bebas risiko tersebut menghasilkan return sebesar 7\% per tahun atau setara dengan 0,00192 per hari, kemudian selebihnya sebesar 90\% dananya diinvestasikan pada aset tanpa bebas risiko yaitu pada 5 (lima) saham terbaik. Ternyata grafik permukaan efisien portofolio hasil kombinasi tanpa dan dengan aset bebas risiko, berada di atas grafik permukaan efisien dari portofolio yang hanya diinvestasikan pada 5 (lima) saham (aset) tanpa bebas risiko. Hal ini menunjukkan bahwa portofolio investasi yang mengkombinasikan tanpa dan dengan aset bebas risiko, lebih menguntungkan dibandingkan dengan portofolio investasi tanpa bebas risiko yang seluruhnya terdiri dari 5 (lima) saham.

\section{Ucapan Terima Kasih}

Ucapan terimakasih disampaikan kepada Program Studi Magister Matematika Fakultas Matematika dan Ilmu Pengetahuan Alam Universitas Padjadjaran, dan Program Studi Pendidikan Matematika STKIP Garut, serta Dewan redaksi Jurnal Matematika Integratif, yang telah memberikan fasilitas untuk melakukan penelitian dan publikasi.

\section{Daftar Pustaka}

1. Bodie, Zvi, Kane, Alex \& Marcus, Alan J., 2014. Invessment, 9th ed. Terjemahan Romi Bhakti Hartarto dan Zuliani Dalimunthe. Jakarta: Salemba Empat, Edisi Global, 2014.

2. Jogiyanto, 2016. Teori Portofolio dan Analisis Investasi. Edisi Kesepuluh. Penerbit BPFE Yogyakarta.

3. Mangram, Myles E., 2013. A Simplified Persepective of the Markowitz Portfolio Theory. Global Journal of Business Research,Vol 7 No. 1, 2013.

4. Moehring, A., 2013. Markowitz Portfolio Optimization with Matrix Algebra. Linear Algebra Term Paper, Spring 2013.

5. Panjer, Harry H.et al, 1998. Financial Economics: With Applications to Invesments, Insurance and Pensions. Printed in United States of America.

6. Ryck, P.D., Cole, F., Smedts, J. \& Moor, L.D., 2007, The Performance Evaluation of Hedge Funds: Are Investors Mislead by Standard Mean-Variance Statistics?, Research Paper, Hogeschool-Universiteit Brussel.

7. Ruppert, D., 2004. Statistics and Finance: An Introduction. New York: Springer-Verlag.

8. Solanki, 2014. Portfolio Selection Process throght Markowitz Model. Indian Journal of Applied Research. Volume 4, Issue 8, Agustus 2014.

9. Tandelilin, E. 2010. Portofolio dan Investasi (Portfolio and Investment). Teori dan Aplikasi (Theory and Application). Edisi Pertama. Penerbit: Kanisius, Yogyakarta. 